\title{
Una oportunidad para ser libres
}

\section{Carolina Mejía}

"Un pedacito, sólo un pedacito y todos seríamos felices", es lo que oía a mi padre decirle a mi madre una y otra vez. "Si sólo ese maldito dictador Díaz cayera y el porfiriato acabara, tal vez habría la oportunidad de mejorar nuestras vidas", agregaba con coraje en la voz. Yo tenía 13 años, pero recuerdo todo como si fuera ayer.

Vivíamos en un jacal de sólo un cuarto, en la tierra del patrón. Mis padres se levantaban con el sol y terminaban de trabajar a la puesta del sol. Todos los días era lo mismo, mientras mis padres trabajaban yo hacía lo mismo, pues le ayudaba a mi padre a trabajar las tierras del patrón y no tenía la oportunidad de ir a la escuela. Y aunque trabajábamos mucho, apenas teníamos para comer, pues el patrón no nos pagaba un sueldo sino con vales que solo podíamos usar en su tienda donde daba todo muy caro. La mayoría de los campesinos estaban endeudados. Mi infancia fue muy difícil pero gracias a Dios y con muchos sacrificios y sufrimiento todo cambió para bien.

Era una noche tormentosa. Y no podía dormir, estaba pensando en todo lo que había escuchado a mi padre decirle a mi madre. Los campesinos estaban planeando unirse a la Revolución y a la lucha por la justicia social y mi padre estaba dispuesto a pelear. Los campesinos y todos los pobres estábamos cansados de ser esclavos y de la dictadura a la cual estábamos sometidos sin poder mejorar nuestras vidas.

Eran las 5 de la mañana cuando empezó todo. "Justicia y tierra", era lo que gritaban los campesinos mientras se dirigían a la casa donde dormía el patrón y su familia. Mi madre me despertó junto con mi hermano y nos llevó al monte para escondernos mientras sucedía todo. Alrededor de las 7 de la mañana salimos del monte para ver qué había sucedido. Los campesinos habían quemado la hacienda del patrón y lo habían asesinado.

Recuerdo ver la cara de María, la hija del patrón, estaba deshecha. Ella no tenía la culpa de nada, pero ya con tan sólo 11 años había quedado sin padre. Su madre se la llevó a la ciudad de México donde no supe nada de ella hasta después de varios años. Desde muy pequeño yo siempre había estado enamorado de ella, sin embargo su padre no dejaba que yo me acercara a ella porque, según él, yo sólo era el hijo de un campesino pobre.

Esto fue sólo el comienzo. Durante los siguientes años, mi familia y yo no tuvimos hogar nos la pasábamos de ciudad en ciudad. A los 15 años me uní a la Revolución junto con mi padre para pelear por la justicia 
social. Mientras nosotros los hombres luchábamos para ser liberados de la injusticia, mi madre junto con varias otras mujeres se quedaba en los campamentos a lavar ropa y preparar comida; sin las mujeres habría sido muy difícil sobrevivir esa Revolución. Recuerdo que hasta los niños de 4 a 5 años ayudaban limpiando las armas cuando no estaban cargadas. La Revolución era una lucha familiar y del pueblo entero donde todos hacíamos lo que podíamos.

El 30 de marzo 1915, la fecha que nunca voy a olvidar, llegamos al estado de Guanajuato. Allí nos encontramos con los del gobierno y eran más de 200 militares mientras nosotros sólo éramos si acaso unos 50. Varios de nuestros compañeros habían muerto en otras batallas y mientras pasaba el tiempo nuestro ejército iba disminuyendo. Ese fue el enfrentamiento con los militares del gobierno me quitó a mi padre. Recuerdo estar escondido detrás de una roca disparando, tumbando uno que otro militar, y fue cuando vi que mi papá estaba ahí tirado sin moverse. Después que se terminó la batalla me acerqué a mi padre y aún estaba con vida. Sus últimas palabras fueron, "Hijo mío, no te preocupes por mí, que yo me voy feliz y tú sigue luchando que yo sé que los campesinos van a triunfar". Yo seguí luchando en la Revolución. Miraba cómo mis compañeros iban cayendo uno por uno. Me empecé a desilusionar pero siempre recordaba lo que me dijo mi padre antes de morir.

Un año después que terminó la Revolución, me mudé a la ciudad de México. Iba con la esperanza de encontrar a María, mi amor desde niño. Tiempo después la encontré. Desafortunadamente ella ya estaba casada, pero me dio gusto saber que María se había casado con el hijo de un campesino. Ahí me di cuenta que la Revolución había cambiado a México para bien. 